\title{
Pedagogia macunaímica: inspirações modernistas para pensar a escola e o Brasil contemporâneo
}

\author{
PEDAGOGÍA MACUNAÍMICA: INSPIRACIÓN MODERNISTA PARA PENSAR EM LA ESCUELA Y \\ EL BRASIL CONTEMPORÁNEO
}

https://orcid.org/0000-0002-2833-0365 Luiz Fernando Conde Sangenis A

${ }^{\text {A }}$ Universidade do Estado do Rio de Janeiro (Uerj), Rio de Janeiro, RJ, Brasil

Recebido em: 7 dez. 2021 | Aceito em: 18 jan. 2022 Correspondência: Luiz Fernando (lfsangenis@gmail.com)

\section{Resumo}

Tendo como motes o centenário da Semana de Arte Moderna de 1922 e o movimento de "giro decolonial", o ensaio se inspira em Macunaíma, rapsódia do modernista Mário de Andrade. De Macunaíma, texto e personagem chispam intuições para o desafiante compromisso de pensar o Brasil contemporâneo e a escola brasileira. Especificamente, desejamos destacar as potências que acompanham a trajetória do herói: a ausência de caráter, a preguiça e a aversão capitalista. Daí propormos uma Pedagogia macunaímica que se configura contrária aos rumos que o capitalismo vai impondo à escola e à sociedade. Sabemos que, sem mexer na estrutura do modelo econômico capitalista e no modo como o capital rentista se reproduz, não haverá verdadeira mudança e desenvolvimento econômico com equidade e inclusão de todos. Pois, não nos parece bom e honesto atrelar a escola a um projeto injusto e desumano, que gera riqueza para poucos e miséria e infelicidade para a maioria. $\mathrm{O}$ que nos resta fazer? Rejeitemo-lo! Contra a escola ocidental capitalista, que transforma o direito à educação em serviço a ser negociado, a pedagogia macunaímica é um salutar antídoto.

Palavras-chave: modernismo; Mário de Andrade; educação; capitalismo, decolonidade.

\section{Resumen}

Teniendo como lemas el centenario de la Semana de Arte Moderno de 1922 y el movimiento del "giro decolonial", el ensayo se inspira en Macunaíma, una rapsodia del modernista Mário de Andrade. Desde Macunaíma, el texto y el carácter despiertan intuiciones para el desafiante compromiso de pensar en el Brasil contemporáneo y la escuela brasileña. En concreto, queremos destacar los poderes que acompañan la trayectoria del héroe: falta de carácter, pereza y aversión capitalista. Por ello, proponemos una pedagogía macunaímica que se configura en contra de los caminos que el capitalismo está imponiendo a las escuelas y la sociedad. Sabemos que, sin cambiar la estructura del modelo económico capitalista y la forma en que se reproduce el capital rentista, no habrá cambio real y desarrollo económico con equidad e inclusión de todos. Porque no parece bueno y honesto vincular la escuela a un proyecto injusto e inhumano, que genera riqueza para unos pocos y miseria e infelicidad para la mayoría. ¿Qué nos queda por hacer? ¡Rechacémoslo! Frente a la escuela occidental capitalista, que transforma el derecho a la educación en un servicio a negociar, la pedagogía macunaímica es un saludable antídoto.

Palabras clave: modernismo; Mário de Andrade; educación; capitalismo; decolonidad. 


\section{Indrodução}

- Paciência, manos! não! não vou na Europa não. Sou americano e meu lugar é na América. A civilização europeia na certa esculhamba a inteireza do nosso

caráter.

Mário de Andrade.

A Semana de Arte Moderna de 1922, organizada entre os dias 13 e 17 de fevereiro, no Teatro Municipal de São Paulo, é o grande pano de fundo do cenário em que transita nosso texto. O evento, organizado por um grupo de intelectuais e artistas - escritores, pintores, escultores, arquitetos, músicos - foi um marco na história da cultura brasileira. O festival incluiu exposição com cerca de 100 obras, aberta diariamente no saguão do teatro, e três sessões líteromusicais noturnas.

O fim da Primeira Guerra Mundial suscitava a transformação das estruturas mentais e políticas das sociedades. Os movimentos das vanguardas europeias (cubismo, futurismo, surrealismo), propiciadores da renovação geral do panorama da arte ocidental, serviram de inspiração aos artistas brasileiros. Aqui, também, houve apelo ao rompimento com o tradicionalismo cultural associado às correntes literárias e artísticas anteriores: o parnasianismo, o simbolismo e a arte acadêmica.

A efeméride do centenário da Independência, sem dúvida, foi o principal ingrediente que fez fervilhar a criatividade dos participantes da Semana de Arte Moderna que não mediram esforços para apresentar suas produções ao grande público. O compromisso com a independência cultural do país, a partir da defesa de um novo ponto de vista estético, fez do modernismo sinônimo de estilo novo diretamente associado à produção realizada sob a influência de 1922. O intento de redefinição da linguagem artística se articulou a um forte interesse pelas questões nacionais. A partir da década de 1930, os ideais de 1922 ganharam novos impulsos e maior difusão, sobretudo em consequência dos rumos políticos do país nesse período. O principal resultado da Semana de 22 foi sua intencionalidade de romper com o conservadorismo vigente no cenário cultural da época.

Apesar de as artes plásticas formarem a principal base do movimento, desejamos destacar a força literária do grupo modernista. Razão pela qual tratamos de uma das mais significativas produções literárias surgida entre os modernistas: Macunaíma. 
A rapsódia de Mário de Andrade (1893-1945), escrita em 1926 e publicada em 1928, ao longo de nove décadas, foi tema de inumeráveis trabalhos críticos e inspiração para tantos outros que buscaram entabular análises sobre as brasilidades e as gentes brasileiras. Macunaíma, tanto designando a narrativa original que produz espanto e prazer, quanto o nome do herói sem nenhum caráter que salta do livro para habitar as entranhas da cultura brasileira, é manancial que faz jorrar potências criativas a antigos e a novos leitores.

De Macunaíma, texto e personagem chispam intuições para o desafiante compromisso de pensar o Brasil contemporâneo e a escola brasileira. Especificamente, desejamos destacar as potências que acompanham a trajetória do herói: a ausência de caráter, a preguiça e a aversão capitalista. Chamamos de potência ao que não podemos definir como traço, característica ou identidade, uma vez que Macunaíma é um herói sem caráter.

Potência ${ }^{i}$ é indeterminação, o não ser ainda, e que supõe o princípio ativo do movimento ou a condição fundamental do devir. Trata-se de uma disposição originária do ser, uma força para promover o movimento ou mudança em outro ou em si mesmo considerado como outro. Potência, portanto, é um elemento de conexão, uma vez que o movimento é sempre de algo para algo. Potência é plasticidade, virtualidade, no sentido de que pode vir a ser muitas coisas.

Há um segundo tipo de potência, a potência reativa ${ }^{\text {ii }}$, que se distingue pela capacidade de se manter imune àquele movimento que não seja condizente com o paciente. É a disposição de reação à mudança para pior e à destruição por outro. Essa impassibilidade frente à mudança para pior se assemelha a um modo de resistência, promovendo um momento de conservação.

Potência, em Macunaíma, manifesta-se mais ao modo da in-disposição, da anti-patia, da re-atividade. A ausência de caráter, a preguiça e a repulsa ao capitalismo têm em comum a falta, a inexistência de algo, a não positividade, a negação, porque o herói carece de laboriosidade, de identidade e de amores ao lucro. Em verdade, o pensamento de Mário de Andrade é ambivalente, oscilando entre a negatividade que acusa nas tramas de Macunaíma o próprio mal-estar na civilização ocidental capitalista, e o vislumbre de uma outra civilização tropical capaz de controverter as prioridades do trabalho e do ócio, da acumulação capitalista e do pensamento técnico-científico.

Não é forçoso dizer que os modernistas tinham em mente o que, mais atualmente,

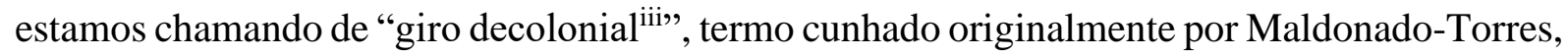
em 2005, e cuja tentativa é a de romper com o referencial eurocêntrico (MIGNOLO, 2010). Significa o movimento de resistência teórico e prático, político e epistemológico à lógica da modernidade/colonialidade. Desta forma, a decolonidade aparece como terceiro elemento da 
modernidade/colonidade. Segundo Maldonado-Torres (2007) o que se aspira é o rompimento com a lógica monológica da modernidade. Há muito de antropofágico no giro decolonial, já que pretendeu uma atitude de devoração ritual dos valores europeus, a fim de superar a civilização patriarcal e capitalista.

A pretensão deste ensaio é a de trazer as contribuições de Mário de Andrade, através de Macunaíma, para esse diálogo atual e necessário, de modo a fazer reverberar as suas consequências no âmbito da educação. E mais que isso. Buscamos encontrar caminhos possíveis que possam ser percorridos, ainda que com riscos, no empenho de superação do que nos aflige em nossas escolas e nas sociedades periféricas nas quais estamos inseridos. Daí propormos uma pedagogia macunaímica que se configura contrária aos rumos que o capitalismo vai impondo à escola e à sociedade. Porque de nada adianta determo-nos na denúncia, caso não se consiga mobilizar mulheres e homens inconformados e, por isso, desejosos em lutar por outra educação e novas escolas que correspondam, mais amplamente, aos anseios e às reais necessidades das populações e dos multivariados grupos sociais, étnicos e sexuais.

\section{Comecemos pela preguiça}

Mais que um elogio à preguiça, Macunaíma é uma sátira aos impulsos negativos do "herói de nossa gente". A preguiça é a potência que mais se destaca em Macunaíma. A preguiça, não necessariamente, é má. Só é patológica, viciosa ou pecaminosa ${ }^{\mathrm{iv}}$ se o trabalho tiver um valor positivo. Em caso contrário, a condenação moral que sobre ela paira não subsiste. $\mathrm{Na}$ tradição greco-romana, a preguiça tornou-se ócio e lazer (scholè em grego, otium em latim), disponibilidade, independência, liberdade. Para os grandes pensadores da Antiguidade clássica o trabalho manual avilta o humano e por isso o condenam. Platão e o Aristóteles filosofam sobre o trabalho considerando-o um mal físico, moral, político e metafísico. Ao trabalho, mal necessário, e do qual se deve tentar escapar o quanto possível, é atividade própria dos escravos e daqueles cuja natureza dispôs à servidão. É o que lemos em A República e na Política.

Os ibéricos e católicos que dominaram a América também não morriam de amores pelo trabalho. Sérgio Buarque de Holanda soube bem distinguir os tipos de colonização que vigoraram na América. Em contraste com a colonização empreendida na América do Norte, caracterizada pela "ética do trabalho", a portuguesa foi tipificada pela "aventura". Quanto a nossa colonização, resumiu-a numa frase de efeito: "seu ideal será colher o fruto sem plantar a 
árvore" (HOLANDA, 1995, p. 44). O colonizador aventureiro visou à exploração dos recursos naturais e do elemento humano, o enriquecimento rápido e o retorno a Portugal.

No Brasil, a consciência de que o trabalho é um castigo divinov ${ }^{\mathrm{v}}$, consequência do pecado de Adão e Eva, expulsos do Jardim do Éden, perdurou por séculos. A crença religiosa associada ao racismo sustentou a sórdida divisão social entre negros, índios e brancos. Aos primeiros, estava reservado o calvário do trabalho, sem perspectivas de redenção; aos senhores de pele alva, por direito e bênção divina, cabiam os frutos e os benefícios do trabalho alheio.

Levando em consideração a pecha que receberam os índios classificados de preguiçosos e indolentes (e a escola ressonou esse terrível preconceito), fomos erroneamente induzidos a pensar que, passado o "ciclo" extrativista com a introdução do negócio do açúcar, os negros se adequariam melhor ao trabalho duro dos engenhos. Quando em verdade, o tráfico negreiro de tal modo se tornou lucrativo para os comerciantes de escravos, que as atividades mercantis escravistas e açucareira impunham-se uma à outra. Todavia, na região amazônica e em São Paulo, a escravidão do índio continuou a servir de meio de vida para os colonizadores. Os amaldiçoados filhos de Cam e os bárbaros silvícolas, avessos à civilidade, eram reduzidos a mais vil servidão sob a infame justificativa de sua inferioridade racial. A chibata e a sujeição eram consideradas os meios mais eficazes para dispô-los ao trabalho e à conversão de suas almas.

O imaginário social brasileiro modificou-se muito lentamente. Em Urupês, Monteiro Lobato (1971) critica as seduções poéticas e literárias indianistas e "caboclistas". Segundo o autor taubateano, não passavam de tentativas imaginosas e idealistas de conferir aos tipos nacionais qualidades nobres e heroicas que não resistiriam a mais crua realidade.

"Morreu Peri", anunciou Lobato (1971, p. 145), referindo-se jocosamente às idealizações literárias que anunciavam um homem natural tal qual sonhava Rousseau, protótipo de tantas perfeições humanas, ombreado com altos tipos civilizados na beleza da alma e do corpo. Contrapunha-se aos "aimorés sanhudos, com virtudes romanas por dentro e penas de tucano por fora" (LOBATO, 1971, p. 145) a cruel etnologia dos sertanistas modernos: "um selvagem real, feio e brutesco, anguloso e desinteressante, tão incapaz, muscularmente, de arrancar uma palmeira, como incapaz, moralmente, de amar Cecí" (LOBATO, 1971, p. 145).

O indianismo, de nome mudado, passou a "caboclismo". Ao caboclo, foi transferido o mesmo substrato psíquico imaginoso: "orgulho indomável, independência, fidalguia, coragem, virilidade heroica, todo o recheio em suma, sem faltar uma azeitona, dos Peris e Ubirajaras" (LOBATO, 1971, p. 146). Lobato (1971, p. 146) jacta em colocar-se entre os "prosaicos 
demolidores de ídolos - gente má e sem poesia”, e que irá "esgaravatar o ícone com as curetas da ciência”. Pois, afinal, “o caboclo é o 'Ai Jesus!' nacional. [...] Pobre Jéca Tatu! Como és bonito no romance e feio na realidade!" (LOBATO, 1971, p. 146;148) ${ }^{\mathrm{vi}}$. Ilusão das ilusões essa do "Jeca mercador, Jeca lavrador, Jeca filósofo...", quando "seu grande cuidado é espremer todas as consequências da lei do menor esforço - e nisso vai longe" (LOBATO, 1971, p. 148).

O estereótipo do caipira devorado pelos vermes enquanto a plantação é devorada pelas saúvas (as mesmas formigas com que Macunaíma se divertia decepando cabeças ${ }^{\text {vii }}$ ) é a personificação da "incompetência cósmica" do Brasil para construção de qualquer projeto de futuro (ANDRADE, 1971). Ao racismo renitente, agregaram-se outras causas para explicar a nossa incompetência como povo e nação - se não em razão da nossa formação étnica, cuja nota da mestiçagem nos inferiorizava -, na consideração de que o povo brasileiro era uma gente castigada pelas doenças do corpo e do espírito ${ }^{\text {viii }}$. Jeca Tatu é preguiçoso e pouco afeito ao trabalho porque sofre de endemias tropicais e de enfermidades cuja causa é a falta de higiene e de asseio.

Mário de Andrade (1918), dez anos antes da publicação de Macunaíma, escreveu Divina Preguiça, texto em que lançou as sementes que germinariam na sua criativa composição do herói preguiçoso. Em resumidas laudas, expressou seu desagrado à propensão que tinham os cientistas de explicar as faltas e os vícios dos homens por meio de doenças e de atavismo: "Reduziam o humano a um joão-minhoca [...]". Mário, num artifício de retórica, continua a esbravejar: "Mais uma ilusão que nos querem tirar!" Pois, se a preguiça já fora tratada, ora como dons dos deuses, ora como pecado mortal, agora, "ei-la reduzida a um morbo de nova espécie! [...] Mas eis que os psiquiatras querem trazer à preguiça mais essa qualificação de doentia [...]. Revoltemo-nos! A preguiça não pode ser reduzida a uma doença! ${ }^{\text {ix }}$.

O ímpeto da modernização, ainda que atrasado, desembarcou no Brasil republicano vestido de positivismo científico e civilizatório. Afinal, era necessário virar a página do Brasil arcaico, escravista e incivilizado. Bacharéis em direito, médicos e engenheiros, tais como Monteiro Lobato, Nina Rodrigues, Pandiá Calógeras, Oswaldo Cruz, Carlos Chagas, Pereira Passos, entre tantos outros, tomaram a dianteira de grandes projetos de modernização do país patrocinados pelo estado. A escola, em especial a escola técnica, seria uma agência importante para a ação civilizatória do estado brasileiro (GONDRA, 2004). Muitas dessas ações, em geral autoritárias, invasivas e violentas, encontraram forte resistência popular. A guerra de Canudos, na Bahia, e a Revolta da Vacina, no Rio de Janeiro, são paradigmáticas. 
Em posição contrária à do criador do Jeca Tatu, cabe considerar que o povo brasileiro resistiu bravamente à atitude de sacrossantificar o trabalho, termo esse utilizado por Paul Lafargue $^{\mathrm{x}}\left(1990\right.$, p. 15) no famoso panfleto revolucionário $O$ direito à preguiça ${ }^{x i}$.

Falemos claramente a verdade: não se trata de desamor ao trabalho; é que a gente brasileira, tipificada em Macunaíma, não gosta de capitalismo, de trabalho explorado. Por isso, custamos tanto a compartilhar da ética do trabalho importada do estrangeiro civilizado. Até os anos finais do século XIX, as gentes que aqui viviam experimentavam o anverso da ética puritana do trabalho, ao modo que foi descrita por Weber (2007), em associação ao espírito do capitalismo. Não o fizemos movidos por ações reflexivas ou por lutas políticas de classes esclarecidas. Antes, tratou-se de reação visceral para preservar a vida durante quatro longos séculos de regime escravista. Nossa reação ao ethos do trabalho e ao capitalismo como sistema racional com a única finalidade de obter lucro, se deveu a uma reação cultural e defesa intuitiva do modo tradicional de ser e de viver.

A arte popular brasileira conseguiu expressar de outra forma o que Lafargue (1990) denunciou através da exaltação à preguiça. A seu modo, souberam promover a conscientização da classe operária, expondo a velhacaria da burguesia, escancarando a mentira e a alienação que existe por trás do trabalho assalariado. O Direito à preguiça surge como exercício retórico e debochado contra a religião do trabalho, disfarce moral da burguesia para sustentar a alienação, a exploração e o sofrimento imposto ao proletariado.

Ante o operariado, "tomado de estranha loucura", brada, ironicamente, Lafargue:

Trabalhem, trabalhem, proletários, para aumentar a fortuna social e as vossas misérias individuais, trabalhem, trabalhem, para que, tornando-vos mais pobres, tenham mais razão para trabalhar e para serem miseráveis. Eis a lei inexorável da produção capitalista (LAFARGUE, 1990, p. 26).

A sua vez, os versos de Clementina de Jesus nada devem ao libelo do marxista preguiçoso.

\author{
Não vadeia Clementina \\ Fui feita pra vadiar \\ Não vadeia, Clementina \\ Fui feita pra vadiar, eu vou... \\ Vou vadiar, vou vadiar, vou vadiar, eu vou \\ Vou vadiar, vou vadiar, vou vadiar, eu vou \\ Energia nuclear \\ O homem subiu à lua \\ É o que se ouve falar \\ Mas a fome continua \\ É o progresso, tia Clementina
}

Revista Interinstitucional Artes de Educar. Rio de Janeiro, V.8, N.1 - pág. 14-33 jan-maio de 2022: "Por uma pedagogia macunaímica”- DOI: 10.12957/riae.2022.65282 
Trouxe tanta confusão

Um litro de gasolina

Por cem gramas de feijão

Não vadeia Clementina

Fui feita pra vadiar

Não vadeia, Clementina

Fui feita pra vadiar, eu vou...

Vou vadiar, vou vadiar, vou vadiar, eu vou

Vou vadiar, vou vadiar, vou vadiar, eu vou

Cadê o cantar dos passarinhos

Ar puro não encontro mais não

É o preço que o progresso

Paga com a poluição

O homem é civilizado

A sociedade é que faz sua imagem

Mas tem muito diplomado

Que é pior do que selvagem

Vai trabalhar, vagabundo, reza o samba enfurecido de Chico Buarque, cuja letra, entretanto, é uma ácida recusa ao valor do trabalho.

Vai trabalhar, vagabundo / Vai trabalhar, criatura

Deus permite a todo mundo / Uma loucura

Passa o domingo em família / Segunda-feira beleza

Embarca com alegria / Na correnteza

Prepara o teu documento / Carimba o teu coração

Não perde nem um momento / Perde a razão

Pode esquecer a mulata / Pode esquecer o bilhar

Pode apertar a gravata

Vai te enforcar / Vai te entregar / Vai te estragar / Vai trabalhar

Vê se não dorme no ponto / Reúne as economias

Perde os três contos no conto / Da loteria

Passa o domingo no mangue / Segunda-feira vazia

Ganha no banco de sangue / Pra mais um dia

Cuidado com o viaduto / Cuidado com o avião

Não perde mais um minuto / Perde a questão

Tenta pensar no futuro / No escuro tenta pensar

Vai renovar teu seguro

Vai caducar / Vai te entregar / Vai te estragar / Vai trabalhar

Passa o domingo sozinho / Segunda-feira a desgraça

Sem pai nem mãe, sem vizinho / Em plena praça

Vai terminar moribundo / Com um pouco de paciência

No fim da fila do fundo / Da previdência

Parte tranquilo, ó irmão / Descansa na paz de Deus

Deixaste casa e pensão / Só para os teus

A criançada chorando / Tua mulher vai suar

Pra botar outro malandro / No teu lugar

Vai te entregar / Vai te estragar / Vai te enforcar / Vai caducar / Vai trabalhar

Revista Interinstitucional Artes de Educar. Rio de Janeiro, V.8, N.1 - pág. 14-33 jan-maio de 2022: "Por uma pedagogia macunaímica”- DOI: 10.12957/riae.2022.65282 
Ariano Suassuna, em A farsa da boa preguiça, de forma burlesca, ainda que num estilo bastante moralizante, consegue também captar a alma popular para quem a gana pelo enriquecimento pode significar, paradoxalmente, uma existência miserável e sem alegria. Simão é pobre, poeta, preguiçoso, escritor de origem rural que, por força das circunstâncias, vive no meio de uma burguesia urbana. Ele é dotado de uma grande capacidade de criação associada a um humor espontâneo e debochado. Aderaldo, casado com a fútil e licenciosa Clarabela, representa o burguês enriquecido graças ao trabalho dos pobres. É um ser lascivo que quer a todo custo possuir a esposa de Simão, Nevinha, que permanece fiel. Ele tenta seduzila, inúmeras vezes, com a promessa de bens materiais. Ligado ao dinheiro, acredita na facilidade de possuir as pessoas da mesma forma que possui as coisas.

No transcurso da farsa, os personagens mudam de sorte, através de uma aposta. Mas, no último ato, encontramos Simão e Nevinha, novamente empobrecidos. Retornam para a antiga e humilde casa, vizinha à do rico Aderaldo, que, através da avareza, volta a acumular riqueza. O texto chega ao fim, quando os demônios vêm buscar as almas do infame personagem e de sua hipócrita mulher. Eles os transportam vivos ao inferno. Simão e Nevinha, no entanto, permanecerão vivos para cumprir seus destinos.

Suassuna tenta estabelecer oposições entre pobreza e miséria, entre riqueza exterior e miséria interior, entre o rico miserável e o pobre feliz, além de reforçar o elogio à preguiça criativa do poeta. Simão é o personagem pobre que se permite rir de sua própria condição. Em sua alegria natural e com riqueza de espírito compreende que "há um ócio criador e há um ócio danado, há uma preguiça com asas outra com chifres e rabo":

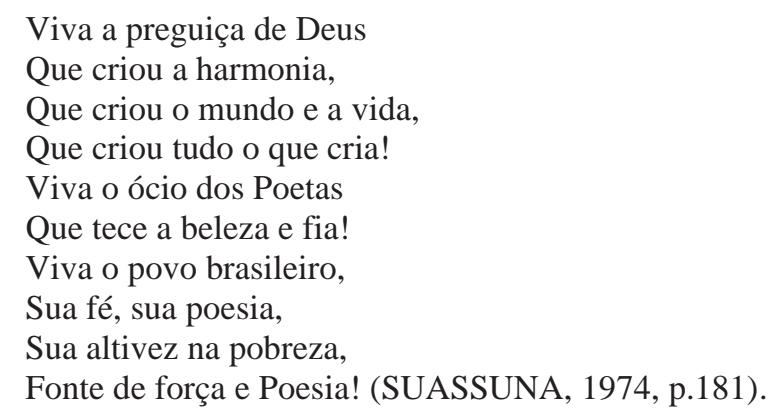

\section{Macunaíma, herói sem caráter}

Macunaíma, além de preguiçoso, é o herói sem nenhum caráter. De que maneira poderemos interpretar esta outra e desconcertante potência? É bom que iniciemos a construir uma resposta recorrendo ao próprio criador de Macunaíma. Mário de Andrade (2015, p. 191), 
no manuscrito do primeiro prefácio que produziu, em 1926, explica o significado que desejou dar a caráter.

O que me interessou por Macunaíma foi incontestavelmente a preocupação em que vivo de trabalhar e descobrir o mais que possa a entidade nacional dos brasileiros. Ora depois de pelejar muito verifiquei uma coisa me parece que certa: o brasileiro não tem caráter. [...] E com a palavra caráter não determino apenas uma realidade moral não em vez entendo a entidade psíquica permanente, se manifestando por tudo, nos costumes na ação exterior no sentimento na língua na História na andadura, tanto no bem como no mal [sic].

No segundo prefácio de 1928, Andrade (2015, p. 197) retoma a circunstância da falta de caráter do herói: "Falta de caráter no duplo sentido de indivíduo sem caráter moral e sem característico".

No terreno fértil das ambiguidades, ainda, no segundo prefácio, Andrade (2015, p. 197) declara: "não quero que imaginem que pretendi fazer este livro uma expressão da cultura nacional. Deus me livre". E, imediatamente, em seguida, diz: "É agora, depois dele feito, que me parece descobrir nele um sintoma da cultura nossa" (2015, p. 197). Macunaíma é a paródia da cultura e da vida nacional. Se o herói não tem caráter, e a despeito da personagem homônima do alemão Theodor Koch-Grünberg ${ }^{x i i}$, é porque tampouco o tem o brasileiro.

(O brasileiro não tem caráter porque não possui nem civilização própria nem consciência tradicional. Os franceses têm caráter e assim os yorubas e os mexicanos. Seja porque civilização própria, perigo iminente ou consciência de séculos tenha auxiliado, o certo é que esses uns têm caráter). Brasileiro (não). Está que nem o rapaz de vinte anos: a gente mais ou menos pode perceber tendências gerais, mais ainda não é tempo de afirmar coisa nenhuma. Dessa falta de caráter psicológico creio otimistamente, deriva a nossa falta de caráter moral. Daí nossa gatunagem sem esperteza, (a honradez elástica/a elasticidade da nossa honradez), o desapego à cultura verdadeira, o improviso, a falta de senso étnico nas famílias. E sobretudo uma existência (improvisada) no expediente (?) enquanto a ilusão imaginosa feito Colombo de figura-de-proa busca com olhos eloquentes na terra um eldorado que não pode existir mesmo, entre panos de chão e clima igualmente bons e ruins, dificuldades macotas que só a fraqueza de aceitar a realidade poderia atravessar. É feio. (ANDRADE, 2015, p. 192) xiii $^{\text {. }}$

Mário de Andrade, entre diversos intelectuais brasileiros, estão imbuídos da vontade de enunciar as chaves de decifração do Brasil. Nas interpretações históricas que foram produzidas, entre os anos 1920 e 1940, não obstante as divergências teóricas e ideológicas, a responsabilidade pelo atraso cultural e socioeconômico do país devia-se a vários fatores: à herança ibérica, à mestiçagem, ao patrimonialismo, à economia dependente, ao predomínio rural e à cultura importada.

Os modernistas também estão engajados na tarefa de delinear a identidade nacional. Se tomarmos os diversos manifestos publicados na imprensa ou na forma de textos, em prosa e verso, é comum que a questão nacional estivesse relacionada com a cultura popular. Em termos 
gerais, o Manifesto Pau-Brasil, o Movimento Antropofágico, o Verde-Amarelismo e o Grupo Anta defendiam a fala coloquial, o combate às influências europeias e a valorização das tradições culturais do Brasil.

Macunaíma não deixa de ser um manifesto. No entanto, ao afirmar que o brasileiro não tem caráter, assim como Macunaíma também não o tem, abre uma questão importante e que, mais tarde, será retomada por Dante Moreira Alves (2017) em O Caráter Nacional Brasileiro. O trabalho, surgido na forma de tese de doutorado, foi defendido em 1954. Em exaustiva análise das raízes conceituais do caráter nacional, a partir da ótica da Psicologia Social, sua crítica da segunda metade do século XIX até meados do século XX, aborda as sucessivas teorias do caráter nacional brasileiro recorrendo às imagens e às formulações construídas pela literatura, pela história e pela sociologia. Parte da Carta de Caminha e dos documentos sobre o país e do movimento nativista, segue examinando a construção da imagem do Brasil e dos brasileiros, apreciando os textos de Euclides da Cunha, Nina Rodrigues, Oliveira Vianna, Arthur Ramos, Manuel Bonfim, Paulo Prado, Gilberto Freyre, Sérgio Buarque de Holanda, Vianna Moog, Caio Prado, Cruz Costa, Roger Bastide, Florestan Fernandes, entre tantos outros. A tamanha massa de traços psicológicos e morais que sai dessas obras deram a Dante a capacidade de afirmar que outra coisa não se trata do que ideologia assentada em preconceitos, estereótipos e visões estrábicas da realidade social. Pois, conforme conclui, "o número e a diversidade de tais características justificam a ideia de que não podemos imaginar sua correspondência com qualquer grupo brasileiro, e muito menos com o brasileiro" (LEITE, 1969, p. 329). Concordemos ou não com Dante, seu trabalho é uma referência para quem trata do caráter brasileiro.

Alfredo Bosi (1988, p. 188), por sua vez, analisando o intento de Mário de Andrade em Macunaíma, consegue sintetizar a discussão: "pensar o povo brasileiro, nossa gente, percorrendo as trilhas cruzadas ou superpostas da sua existência selvagem, colonial e moderna, à procura de uma identidade que, de tão plural que é, beira a surpresa e a indeterminação; daí ser o herói sem nenhum caráter”.

Para trazer mais desafio à questão, agregamos um dos últimos trabalhos de Francisco de Oliveira que se aventurou a tratar sobre o caráter nacional. Inspirado em Norbert Elias, autor de Os alemães, Oliveira (2012) pretendeu investigar o caráter brasileiro, tematizando "o famoso jeitinho brasileiro":

Eis a tese: o jeitinho é um atributo das classes dominantes brasileiras que se transmitiu às classes dominadas. Conforme Marx e Engels de A ideologia alemã, as ideias e os hábitos das classes dominantes transformam-se em hegemonia e caráter nacional. No 
Brasil, a classe dominante burlou de maneira permanente e recorrente as leis vigentes, sacadas a fórceps de outros quadros históricos. O drible constante nas soluções formais propicia a arrancada rumo à informalidade generalizada. E se transforma, ao longo da perpétua formação e deformação nacionais, em predicado dos dominados. Essa situação, que é social, se configura no malandro, o especialista no logro e na trapaça.

A burla das classes dominantes brasileiras às normas, desde as capitanias hereditárias, diz Oliveira, ao contrário de atávico ou caso de mau-caratismo, um dado subjetivo, "é uma forma de adotar o capitalismo como solução incompleta na periferia do sistema. Incompleta porque o capitalismo trouxe para cá a revolução das forças produtivas, mas não as soluções formais da civilidade". As classes dominantes, para garantir a coesão de um sistema truncado e garantir a exploração, então "se viram”, dão um jeitinho.

Para vários intérpretes do Brasil, a herança ibérica é importante nota da nossa cultura. Polêmica, é tratado de forma positiva ou negativa. Para uns, a herança ibérica é fardo e problema, e para outros solução e utopia. O iberismo, de um lado, explicaria nosso fracasso como país moderno, uma vez que não nos entregamos totalmente à modernidade; de outro, seria a chance e a possibilidade de negociação dos termos da nossa adesão ao mundo moderno, a partir da diferença e do caráter do povo e da nação brasileira. Portanto, seria necessário buscar nas nossas raízes os elementos que nos tornam típicos como povo e que tem de ser considerados para pensar a nossa modernidade. Não seria essa intencionalidade da antropofagia modernista? Todavia, os elementos que nos tipificam e nos fazem originais, também atrapalham a nossa existência. Em suma, a herança ibérica explicaria o aspecto moroso e retardatário de nossa modernização.

O iberismo se realizou na vida brasileira, desde a Colônia, em contato com as outras etnias e influências que também partilharam essa experiência, em especial, brasilíndios e afrobrasileiros. No iberismo, estão presentes o jesuitismo e o franciscanismo, por certo, duas vertentes indeléveis das formas de transmissão da cultura do colonizador. Sobre os jesuítas, temos estudos bastante abrangentes, sobretudo da área da história e da educação. Sobre franciscanos, muito poucos, apesar de sua relevância nas Américas e no Brasil. Jaime Cortesão (1965), português, e Gilberto Freyre (1959), pernambucano, concordam acerca da significativa influência do franciscanismo sobre o ethos ibérico. O espírito e a práxis franciscana, marcados pela pobreza, o despojamento e a não-acumulação, podem ser descritos como anticalvinista, anticapitalista e antiburguês.

Daí que não gostamos de capitalismo, a começar das nossas elites que sempre desejam ter o estado como sócio e jamais arriscam ou partem para a competição, ante o jogo de cartas 
marcadas, quando se fazem os acordos espúrios em licitações fraudulentas para que todos os envolvidos tirem o seu quinhão das verbas públicas. Vigora no empresariado nacional a total aversão ao risco. É mais uma nota do jeitinho brasileiro.

\section{Por uma pedagogia macunaímica}

A escola foi uma das instituições mais bem-sucedidas no século XX. As populações modernas acreditaram na proposta utópica da escola como um meio eficaz de promover o acesso ao mundo do trabalho e a uma ansiada cidadania. Mas o projeto escolar, no século XXI, parece malogrado. Há uma percepção de que a escola não conseguiu entregar às sociedades boa parte do que prometeu.

As desigualdades, inclusive aquelas que são produzidas pelo próprio sistema escolar brasileiro dualista, aumentam, ao invés de diminuir. Assim entendemos a intencionalidade da reforma do ensino médio brasileiro, efetivada por Medida Provisória (MPV 746/2016), sem debates com os professores, os alunos, os especialistas ou com a sociedade em geral. A escola passará a aligeirar a formação geral, tornando obrigatório apenas o ensino de português e matemática, e priorizando o ensino técnico profissionalizante, despejando no mercado uma legião de jovens que estará fadada a se inserir de forma subalterna no mundo do trabalho. $\mathrm{O}$ direito à educação pública, gratuita e de qualidade é apenas um de uma série de outros direitos que vêm sendo arrancados dos trabalhos numa nova onda que recrudesce o projeto neoliberal em curso, desde os anos noventa do século XX.

A escola também não consegue mais responder eficaz e velozmente às solicitações das sociedades que se transformam em função do avassalador desenvolvimento tecnológico e das novas exigências cognitivas. $\mathrm{O}$ período de dois anos em que estamos imersos na maior pandemia do século, a de Sars-Covid-19, esgarçou o tecido social marcado por crescente desigualdade socioeconômica e tecno-digital. A escola deseja se transformar, mas parece que não sabe como o fazer. É fato que a escola não mais controla e domina a tecnologia de que necessita para se reinventar. Coloca-se, então, numa posição frágil de mera consumidora de teorias e dos produtos e serviços que as acompanham oferecidos pelas empresas de infocomunicação e de tecnologia. A educação tornou-se um grande mercado a ser explorado pela iniciativa do capital. Mesmo em relação às nossas universidades, o risco que corremos, no Brasil e na América Latina, é a consecução do projeto do capital interessado em transformá-las em grandes escolões treinadores de mão de obra especializada, mas com nível acadêmico e técnico-científico tão ruim que não darão às pessoas por elas formadas chances reais de disputar 
as colocações de maior prestígio e melhor remuneração num cenário cada vez mais competitivo. Eis o abismo para o qual tentam nos empurrar.

Tragicamente, podemos, então, parafrasear Lafargue: estudem, estudem, filhos do proletariado, para aumentar a fortuna social e as vossas misérias individuais, estudem, estudem, para que, tornando-vos mais pobres, tenham mais razão para trabalhar e para serem miseráveis. Eis a lei inexorável da educação rendida à sanha empresarial e capitalista.

Sabemos que, sem mexer na estrutura do modelo econômico capitalista e no modo como o capital rentista se reproduz, deslocado da economia real, não haverá verdadeira mudança e desenvolvimento econômico com equidade e inclusão de todos.

Segundo o relatório da Oxfam Brasil (2017) A Distância Que Nos Une, em relação à renda nacional, o $1 \%$ mais rico da população recebe, em média, mais de $25 \%$ de toda a renda nacional, e os $5 \%$ mais ricos abocanham o mesmo que os demais $95 \%$. Uma pessoa que recebe um salário mínimo mensal levaria quatro anos trabalhando para ganhar o mesmo que o $1 \%$ mais rico ganha em um mês, em média. Seriam necessários 19 anos de trabalho para equiparar um mês de renda média do 0,1\% mais rico. Essa enorme concentração é resultado de um topo que ganha rendimentos muito altos, mas, sobretudo, de uma base enorme de brasileiros que ganha muito pouco.

Os números, que já expressam o aprofundamento da nossa tragédia social e econômica, com a pandemia, são ainda mais desfavoráveis à população e aos trabalhadores. No entanto, ao mesmo tempo, o país passou a ter 40 novos representantes na lista de bilionários de 2021 da Forbes. Segundo a revista, os desafios do último ano esquentaram o mercado de capitais e favoreceram ainda mais o clube dos superricos (CASTRO, 2021). Enquanto conseguimos aumentar o número de bilionários, reduzimos a renda que advém do trabalho. Em 2020, 40,1\% da população brasileira (84,7 milhões) tinham rendimento do trabalho e 28,3\% (59,7 milhões) tinham rendimento proveniente de outras fontes. Frente a 2019, houve redução da parcela correspondente ao rendimento do trabalho, que era de 44,3\% (92,8 milhões) no ano anterior, e aumento do peso do rendimento de outras fontes, que correspondia a 23,6\% (49,5 milhões). Essa tendência ocorreu em todas as regiões do país (IBGE, 2021).

De que adianta a escola formar para a empregabilidade, se o mercado não tem como absorver boa parte da mão de obra disponível? A economia é posta à prova não apenas por sua capacidade de autossustentar-se em crescimento, mas, sobretudo, por uma exigência de manterse competitiva no mercado mundial. E isso só pode ser feito mediante a maior automatização 
da produção, com a consequente exclusão dos trabalhadores, e a redução dos custos produtivos, principalmente, através da diminuição nominal dos salários pagos e dos encargos trabalhistas.

Cabe, ainda, lembrar das crianças e dos jovens que foram expulsos da escola pela lógica vigente na sociedade e no sistema escolar. No Brasil, é a minoria que termina a educação básica e que ascende ao ensino superior, bastando que nos reportemos às próprias estatísticas oficiais. Com a pandemia, os índices de evasão e abandono escolar voltaram a aumentar. Os dados da PNAD Contínuas de 2021 estimam que 244 mil crianças e adolescentes entre 6 e 14 anos estavam fora da escola no segundo trimestre de 2021. O número representa um aumento de $171 \%$ em comparação a 2019, quando 90 mil crianças estavam fora da escola.

Não nos parece bom e honesto atrelar a escola a este projeto injusto e desumano, que gera riqueza para poucos e miséria e infelicidade para a maioria. $\mathrm{O}$ que nos resta fazer? Rejeitemo-lo! Contra a escola ocidental capitalista, que transforma o direito à educação em serviço a ser negociado, a pedagogia macunaímica é um salutar antídoto. Façamos "corpo mole”! Porque não é esta a escola e a sociedade que desejamos, nem para nós, nem para nossos filhos.

A história é o espaço da liberdade e da responsabilidade humanas. Essa convicção desautoriza todos os tipos de fatalismos e de triunfalismos, porque o futuro histórico está aberto, e dele, o que se pode prever, nesta exata colocação no tempo, é a indeterminação.

Chegou o momento de propormos uma virada decolonial no âmbito da educação. Faz todo o sentido promover a pedagogia macunaímica, cuja essência é a boa preguiça, pensando a educação a partir da rua, lugar público dos que "vadeiam", dos que sobraram, dos sem mérito, dos sem diploma ou dos portadores de diplomas inflacionados (BOURDIEU, 2007), dos inclassificáveis, dos que foram considerados inapetentes para o aprendizado e incapazes de concorrer na luta diária por sobrevivência por causa da cor da pele, da "degenerescência" biopsicológica ou do sexo.

Como defende Mignolo (2003), não se trata da substituição de um novo paradigma nos termos de Kuhn, mas do surgimento de "paradigmas outros": econômicos, sociais, culturais, educacionais, epistemológicos, sexuais.

Não há novo futuro se não desafiarmos os fatalismos, ironizarmos os triunfalismos e proclamarmos que uma nova história é possível e que os seus protagonistas, paradoxalmente, são os excluídos da história anterior (GIRARDI, 1996).

Há quinhentos anos acumulamos malsucedidas experiências de educação colonizadora. Passamos pela hegemonia escolar jesuítica, pela reforma pombalina, pela doutrina positivista, 
pelo ideário liberal escolanovista, pelo tecnicismo, até chegarmos ao projeto do capital humano dos economistas neoliberais e globalistas. Todas essas ações se encontram na medida em que são empreendimentos da colonialidade/modernidade voltados para organizar sociedades consideradas selvagens, bárbaras ou atrasadas, a partir de ideais alheios as suas culturas. Acreditou-se que os males produzidos pela imposição dos padrões modernizadores seriam minimizados, uma vez que dariam aos povos colonizados as condições de usufruir das conquistas da civilização (ocidental), da modernidade e do progresso da humanidade.

Anísio Teixeira (1976, p. 11) já havia chamado a atenção para a forma como a escola foi transplantada para o Brasil, a partir de modelos europeus: "A verdade é que a escola, como instituição, não pode verdadeiramente ser transplantada. Tem que ser recriada em cada cultura, mesmo quando essa cultura seja politicamente o prolongamento de uma cultura matriz".

A declarada recriação, a partir das matrizes culturais de nossas gentes, jamais foi seriamente empreendida. As lutas dos pioneiros da Escola-Nova pela implantação de um sistema público de ensino único, acessível a todos, não conseguiu ir mundo além do que criar uma nova modalidade de escola para o povo (um todo indiferenciado) com a finalidade de moralizá-lo e adaptá-lo à sociedade produtiva através do trabalho alienado. Foi o que propôs Fernando de Azevedo, no Manifesto de 32, sob o endosso de ilustres signatários.

É certo que é preciso fazer homens, antes de fazer instrumentos de produção. Mas, o trabalho que foi sempre a maior escola de formação da personalidade moral, não é apenas o método que realiza o acréscimo da produção social, é o único método susceptível de fazer homens cultivados e úteis sob todos os aspectos. (MANIFESTO, 2006, p. 192).

Segundo Mignolo (2010), a origem do pensamento decolonial é bastante remota, emergindo desde a fundação da modernidade/colonialidade. A genealogia do pensamento decolonial é planetária e não se limita a indivíduos, mas incorpora nos movimentos sociais populares, indígenas e afros (MIGNOLO, 2008).

Ao fomentar o que Dussel (2000) denominou de "transmodernidade", MaldonadoTorres faz um convite ao diálogo para pensar a modernidade/colonialidade de forma crítica. A transmodernidade envolve uma ética dialógica radical e um cosmopolitismo decolonial crítico, de modo que apenas pode surgir a partir de posições e de acordos com as múltiplas experiências dos sujeitos que sofrem as consequências das diversas formas da colonialidade do poder, do saber (QUIJANO, 2000) e do ser (MALDONADO-TORRES, 2007).

Mas nem tudo se perdeu! Encontramos uma chama viva nos movimentos populares. As organizações populares compreenderam que a luta fundamental não é por mais escolas, mas por outras escolas. Pois, "na oposição ao que existe passa a se gestar um novo projeto educativo, 
a vontade coletiva de uma nova escola porque existe a necessidade de construir uma nova sociedade." (SPOSITO, 1993, p. 184).

No âmbito da educação, acreditar nos agrupamentos populares como sujeitos da educação é uma fonte de fidelidade libertadora e uma bússola em meio ao horizonte nebuloso das dificuldades e confusões atuais. Constitui, portanto, um marco para identificar, em cada momento, não tanto respostas imediatas aos problemas, mas a direção da busca e do compromisso.

Na narrativa macunaímica, encontramos uma inspiração tropicalista para controverter as principais linhas de classificação que constituíram a formação do capitalismo mundial colonial/moderno no século XVI: racismo, eurocentrismo epistêmico e ocidentalização. Se Macunaíma é um herói da nossa gente, não o será na perspectiva do homem heterossexual / branco / patriarcal / cristão / militar / capitalista europeu que chegou ao Brasil para impor os seus próprios padrões hierárquicos globalizantes sob o disfarce da universalidade. Daí a atitude de resistência popular ser interpretada como preguiça, seja por cinismo, seja por incapacidade epistêmica das elites dominantes. A ruptura com o processo hegemônico de dominação só se dará quando os povos e as culturas indo-afro-americanas e populares assumirem o seu lugar de sujeitos históricos, políticos, sociais, educacionais e epistêmicos.

Chegando ao fim, encontramos num texto de Faria (1999) uma faceta pouco conhecida do poeta Mário de Andrade: a de educador. Em 1935, idealizou e criou os Parques Infantis, quando esteve à frente do Departamento de Cultura da Prefeitura de São Paulo (1935-1938).

Os parques infantis [..] podem ser considerados como a origem da rede de educação infantil paulistana - a primeira experiência brasileira pública municipal de educação (embora não-escolar) para crianças de famílias operárias que tiveram a oportunidade de brincar, de ser educadas, cuidadas, de conviver com a natureza, de movimentaremse em grandes espaços [...]. Lá produziam cultura e conviviam com a diversidade da cultura nacional, quando o cuidado e a educação não estavam antagonizados, e a educação, a assistência e a cultura estavam macunaimicamente integradas, no tríplice objetivo parqueano: educar, assistir e recrear. (FARIA, 1999, p. 61-62).

Pensando especialmente nos filhos dos operários, Mario de Andrade concebia uma experiência pedagógica que tivesse por base o jogo e a brincadeira como atividades lúdicas ociosas. O exercício da preguiça, cantada em Macunaíma, ganhava nos Parques Infantis uma dimensão educativa da maior importância: enquanto estão no parque, as crianças brincam, porque não devem trabalhar.

\section{Referências}


ANDRADE, Mário. Divina Preguiça. A Gazeta, São Paulo, 03 de set. 1918, Ano XIII - n. 3.790 .

Macunaíma: o herói sem nenhum caráter. Rio de Janeiro: Nova Fronteira, 2015.

ANDRADE, José Oswald de Souza. Serafim Ponte Grande. 2. ed. Rio de Janeiro: Civilização Brasileira, 1971.

AQUINO, Santo Tomas de. Suma de Teología. Parte II, 2. ed. Madrid: BAC, 1989.

Disponível em: 〈https://sumateologica.files.wordpress.com/2009/09/sumadeteologia2.pdf $>$.

Acesso em: 25 set. 2017.

BOSI, Alfredo. Céu, inferno: ensaios de crítica literária e ideológica. São Paulo. Duas Cidades/Editora 34, 1988.

BOURDIEU, Pierre. A distinção: crítica social do julgamento. São Paulo: Edusp, Porto Alegre: Zouk, 2007.

CASTRO, Mariangela. Quem são os 40 novos bilionários brasileiros no ranking 2021.

Revista Forbes, AGO. 2021. Disponível em: <https://forbes.com.br/forbes-

money/2021/08/quem-sao-os-40-novos-bilionarios-brasileiros-no-ranking-2021/>. Acesso em: 06 dez. 2021.

CORTESÃO, Jaime. O humanismo universalista dos portugueses: a síntese histórica e literária. Lisboa: Portugália, 1965.

DUSSEL, Enrique. Europa, modernidad y eurocentrismo". In: LANDER, Edgardo (Coord.). La colonialidad del saber: eurocentrismo y ciencias sociales, perspectivas latino-americanas. Buenos Aires: Clacso, 2000.

FARIA, Ana Lúcia Goulart de. A contribuição dos parques infantis de Mário de Andrade para a construção de uma pedagogia da educação infantil. Educação \& Sociedade, ano XX, $\mathrm{n}^{\circ}$ 69, p. 60-91, dez, 1999.

FREYRE, Gilberto. A propósito de frades: sugestões em tôrno da influência de religiosos de São Francisco e de outras ordens sôbre o desenvolvimento de modernas civilizações cristãs, especialmente das hispanicas no trópicos. Salvador: Livraria Progresso Editora, 1959.

GIRARDI, Giulio. Os excluídos construirão a nova história?: o movimento indígena, negro e popular. São Paulo: Ática, 1996.

GONDRA, José Gonçalves. Artes de civilizar: medicina, higiene e educação escolar na corte imperial. Rio de Janeiro: Eduerj, 2004.

HOLANDA, Sérgio. Raízes do Brasil. 26. ed. São Paulo: Companhia das Letras, 1995. 
IBGE. PNAD Contínua 2020: queda na ocupação eleva participação das transferências de renda no rendimento domiciliar, Agência de Notícias IBGE, Brasilia, nov. 2021. Disponível em: $<$ https://agenciadenoticias.ibge.gov.br/agencia-sala-de-imprensa/2013-agencia-denoticias/releases/32280-pnad-continua-2020-queda-na-ocupacao-eleva-participacao-dastransferencias-de-renda-no-rendimento-domiciliar>. Acesso em: 06 dez. 2021.

LAFARGUE, Paul. O Direito à Preguiça e outros textos. São Paulo: Mandacaru 1990.

LEITE, Dante Moreira. O caráter nacional brasileiro. São Paulo: Pioneira, 1969.

LOBATO, Monteiro. Urupês. Obras Completas de Monteiro Lobato, Vol. 1. São Paulo: Editora Brasiliense, 1971.

MALDONADO-TORRES, Nelson. Sobre la colonialidad del ser: contribuciones al desarrollo de un concepto. In: CASTRO-GOMEZ, Santiago; GROSFOGUEL, Ramon (coord.) El giro decolonial: reflexiones para uma diversidad epistêmica más allá del capitalismo global. Bogota: Siglo del Hombre Editores; Universidad Central; Instituto de Estudios Sociales Contemporaneos; Pontificia Universidad Javeriana; Instituto Pensar, 2007.

MANIFESTO dos Pioneiros da Educação da Educação Nova (1932). Revista HISTEDBR Online, Campinas, n. especial, p.188-204, ago. 2006. Disponível em: <http://www.histedbr.fe.unicamp.br/revista/edicoes/22e/doc1_22e.pdf >. Acesso em: 19 set. 2017.

MIGNOLO, Walter. Historias locales/disenos globales: colonialidad, conocimientos subalternos y pensamiento fronterizo. Madrid: Akal, 2003.

La opcion decolonial: desprendimiento y apertura. Um manifiesto y un caso. Tabula Rasa, n.8, p. 243-282, 2008.

Desobediencia epistémica: retórica de la modernidad, lógica de la colonialidad y gramática de la descolonialidad. Argentina: Ediciones del signo, 2010.

OLIVEIRA, Francisco. Jeitinho e jeitão. Revista Piauí. n. 73, out. 2012. Disponível em: <https://piaui.folha.uol.com.br/materia/jeitinho-e-jeitao> Acesso em: 05 dez. 2021.

OXFAM BRASIL. A distância que nos une. São Paulo: Oxfam Brasil, 2017. Disponível em: <https://www.oxfam.org.br/a-distancia-que-nos-une>. Acesso em: 25 set. 2017.

QUIJANO, Anibal. Colonialidad del poder y clasificacion social. Journal of World-Systems Research, v. 11, n. 2, p. 342-386, 2000.

RODRIGUES, Nina. As raças humanas e a responsabilidade penal no Brasil. 3. ed. Rio de Janeiro: Companhia Editora Nacional, 1938. Brasiliana Eletrônica. Disponível em: $<$ http://www.brasiliana.com.br/brasiliana/colecao/obras/67/As-racas-humanas-e-aresponsabilidade-penal-no-Brasil>. Acesso em: 25 set. 2017.

SPOSITO, Marília Pontes. A ilusão fecunda: a luta por educação nos movimentos populares. São Paulo: Hucitec, 1993. 
SUASSUNA, Ariano. A farsa da boa preguiça. Rio de Janeiro: José Olympio, 1974.

TEIXEIRA, Anísio. Valores Proclamados e valores reais nas instituições escolares brasileiras. In: MEC. Educação no Brasil: Textos Selecionados. Rio de Janeiro: MEC, 1976.

WEBER, Max. A ética protestante e o espírito do capitalismo. 6. reimpressão, São Paulo: Companhia das Letras, 2007.

\footnotetext{
${ }^{\text {i }}$ Potência (dynamis) é um conceito pertinente à filosofia de Aristóteles. Potência ganha sentido quando contraposto ao ato. Aristóteles, ao preferir os exemplos, não oferece uma definição, nem do ato, nem da potência, considerando que não se deve definir tudo, pois é preciso contentar-se em compreender a analogia.

${ }^{\text {ii }}$ Aristóteles refere-se a esse tipo de potência como disposição de apatia (hésis apatheías).

iii Em língua portuguesa a palavra virada traduz com eficácia o termo giro, do castelhano.

iv A preguiça (pigritia) ou recusa ao trabalho só se torna um pecado capital com a proximidade do capitalismo burguês. Até então, entre os sete pecados capitais, havia o pecado da acídia, cujo sentido nada tem a ver com o que conotamos com a palavra preguiça. A acídia (akedia), termo que foi perdendo o sentido com o movimento de secularização, foi substituído por preguiça. A acídia é o tédio ou a tristeza em relação aos bens interiores e aos bens do espírito. São Tomás define a acídia como a negligência pela qual alguém recusa adquirir os bens espirituais por causa do trabalho adjunto (Suma de Teología, questão 84, artigo 4). A acídia costumava perturbar, sobretudo, os monges, tornando-os descuidados e indiferentes em relação ao cultivo da vida espiritual.

${ }^{v}$ Não é demais lembrar que a palavra latina que dá origem ao nosso vocábulo trabalho é tripalium, instrumento de tortura para empalar (de palus, estaca ou poste) os condenados à morte.

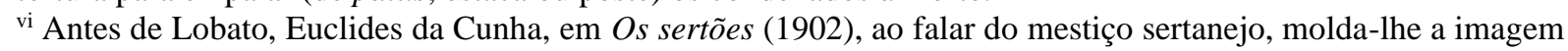
do "Hércules-Quasímodo".

vii A formiga é o símbolo do trabalho e da laboriosidade produtivistas, virtudes tão apreciadas pelo capitalismo.

viii Entre os cientistas brasileiros, Nina Rodrigues é apontado como o que melhor desenvolveu as relações entre doença mental, raça, mestiçagem e criminalidade. As raças humanas e a responsabilidade penal no Brasil, editado em 1894, é considerada uma de suas mais importantes obras.

ix Publicado no jornal A Gazeta, São Paulo, 03 set.1918, Anno XIII - n. 3.790.

${ }^{x}$ Lafargue nasceu em Cuba, neto de uma mestiça de Santo Domingo por parte de pai e de uma índia caribenha com um judeu de origem francesa por parte de mãe. Ainda criança, transferiu-se para Bourdeaux, na França, onde, mais tarde, formou-se em medicina. Na Inglaterra, conheceu Marx e Engels. Desposou Laura, filha de Marx, e foi um dos principais responsáveis por disseminar as teorias de Marx na França.

${ }^{x i}$ Foi publicado a primeira vez em 1880.

xii Etnógrafo alemão e compilador de lendas narradas por índios da Amazônia. O nome do herói foi assumidamente colhido por Mário de Andrade na obra Von Roroima zum Orinoko, Volume 2, Mythen und Legenden der Taulipang und Arekumá Indianen, surgida em 1924 (Stuttigart: Stroeker \& Schroeder).

xiii Em se tratando de um texto manuscrito, feito em folhas de caderno, e que, por certo, mereceria ainda algum tratamento, até chegar a uma versão definitiva, a sua reprodução manteve as imprecisões da escrita e os textos entre parênteses.
} 